\title{
Anaplastic Multiple Myeloma: Case Series and Literature Review
}

Jian $\mathrm{Wu}^{1}$, Emily Chu ${ }^{1}$, Cristiana Costa Chase ${ }^{1}$, Taewoong Choi ${ }^{1}$, Cristina Gasparetto ${ }^{1}$, Ken Young ${ }^{2}$, Yubin Kang $^{1^{*}}$

${ }^{1}$ Division of Hematologic Malignancies and Cellular Therapy, Department of Medicine, Duke University Medical Center, Durham, North Carolina, USA

${ }^{2}$ Division of Hematopathology, Department of Pathology, Duke University Medical Center, Durham, North Carolina, USA

Corresponding Author: Yubin Kang ${ }^{\text {ORCID iD }}$

Address: Division of Hematologic Malignancies and Cellular Therapy, Department of Medicine, Duke University Medical Center, Durham, North Carolina, USA; Email:yubin.kang@duke.edu

Received date: 13 December 2021; Accepted date: 08 January 2022; Published date: 15 January 2022

Citation: Wu J, Chu E, Chase CC, Choi T, Gasparetto C, Young K, Kang Y. Anaplastic Multiple Myeloma: Case Series and Literature Review. Asp Biomed Clin Case Rep. 2022 Jan 15;5(1):1-11.

Copyright (C) $2022 \mathrm{Wu}$ J, Chu E, Chase CC, Choi T, Gasparetto C, Young K, Kang Y. This is an open-access article distributed under the Creative Commons Attribution License, which permits unrestricted use, distribution, and reproduction in any medium provided the original work is properly cited.

\section{Abstract}

Background: Anaplastic multiple myeloma (AMM) is a very rare but distinct subtype of multiple myeloma (MM) with an extremely poor prognosis. Due to its rarity, AMM lacks detailed descriptions and clear definitions. Moreover, there is no consensus on the treatment and evidence suggests that AMM responds poorly to several novel therapies. We conducted a literature review and retrospective case series to determine clinical characteristics, pathological features, and outcomes of AMM.

Case Presentation: Published case reports and case series of AMM since 1983 were systematically extracted and reviewed. A total of 52 patients with AMM were reported in the PUBMED since 1983, including 26 males (50\%) and 26 females (50\%). The age ranged from 29 years old to 85 years old, with a mean age of 57.02 years old. Most of the patients presented with bone pain $(23,44.2 \%)$, fatigue $(18,34.6 \%)$, plasmacytoma $(18,34.6 \%)$ and weight loss $(7,13.5 \%)$. The median survival of the patients was 4 months. To investigate the outcomes of patients with AMM in the current era of treatment, a series of 14 patients with AMM diagnosed at our institute between December 2012 and July 2021was retrospectively analyzed. Our retrospective case series consisted of 12 males $(85.7 \%)$ and 2 females (14.3\%), with a mean age of 59 years old. Most of our AMM patients displayed bone lytic lesions as a common manifestation. The common cytogenetic abnormality was 1q amplification. All patients received standard combination chemotherapy consisting of proteasome inhibitors and/or immunomodulatory agents, and half of the patients underwent autologous hematopoietic stem cell transplantation. The median progression-free survival (PFS) and overall survival (OS) for our 14 AMM patients were 0.84 years and 1.52 years, respectively, which was significantly worse than the regular MM patients treated at our institute from 2003-2013 who had a PFS of 2.28 years and OS of 4.92 years.

Conclusions: AMM is a very rare, morphologically distinct variant of MM. It has adverse cytogenetics and an aggressive course. It is often resistant to standard chemotherapy and presents with an extremely low survival rate.

\section{Keywords}

Anaplastic Multiple Myeloma, Multiple Myeloma, Case Series, Treatment, Prognosis

\section{Abbreviations}


Citation: Wu J, Chu E, Chase CC, Choi T, Gasparetto C, Young K, Kang Y. Anaplastic Multiple Myeloma: Case Series and Literature Review. Asp Biomed Clin Case Rep. 2022 Jan 15;5(1):1-11.

AMM: Anaplastic Multiple Myeloma; MM: Multiple Myeloma; PFS: Progression Free Survival; OS: Overall Survival; MGUS: Monoclonal Gammopathy of Undetermined Significance; CKS1B: Cyclin Kinase Subunit 1B; EMP: Extramedullary Plasmacytoma; PBL: Plasmablastic Lymphoma

\section{Background}

Anaplastic multiple myeloma (AMM), also known as plasmablastic plasma cell myeloma, is an extremely rare disease with an aggressive clinical course and unfavorable prognosis. It was first described in 1983 by Foucar et al [1], who reported two patients who developed anaplastic myeloma associated with the extramedullary disease with a prominent intraabdominal and retroperitoneal tumor mass. AMM can present de novo at disease onset, but can also transform from conventional plasma cell myeloma, and the transformation typically occurs between the first and fourth year of the diagnosis of multiple myeloma (MM). The prognosis of patients with AMM is extremely poor with current treatment and most of AMM patients live for only a few months after diagnosis [2]. The exact incidence of AMM is not clear. It was estimated that in approximately $2.6 \%$ of plasma cell myelomas, the morphology of the plasma cells was highly pleomorphic, quite anaplastic, and may resemble that of metastatic tumor cells. Due to the rarity of the disease, only a limited number of AMM cases have been reported and there is a lack of a systemic approach for the understanding and the management of this disease. In the current study, we conducted a literature review and performed a retrospective study of $14 \mathrm{AMM}$ patients seen at our institute in an effort to further analyze the clinical and pathological features of AMM patients and to provide some suggestions for diagnosis and treatment.

\section{Cases Presentation}

\section{Literature Review:}

We searched PubMed for articles with the keywords: anaplastic myeloma and plasmablastic multiple myeloma; we then filtered for articles published in the English language and involved human patients since 1983. We included all original case reports and case series, and all articles were individually reviewed. Clinical characteristics and outcomes were extracted.

We searched PUBMED for publications reporting AMM case(s) between 1983 and 2021. We found twenty-three articles that met the criteria [1-23]. A total of 52 anaplastic myeloma cases were reported during the period between 1983 and 2021: 26 were

Table-1: AMM: Patient Characteristics, Treatment, and Outcomes: literature review

\begin{tabular}{|c|c|}
\hline & $\begin{array}{c}\text { Patients }(n=52) \\
\text { No. }(\%)\end{array}$ \\
\hline \multicolumn{2}{|l|}{ Gender } \\
\hline Male & $26(50 \%)$ \\
\hline Female & $26(50 \%)$ \\
\hline \multicolumn{2}{|l|}{ Age (yrs) } \\
\hline Mean & 57.02 \\
\hline Range & $29-85$ \\
\hline \multicolumn{2}{|l|}{ Race } \\
\hline Caucasian & $2(3.8 \%)$ \\
\hline Asian American & $18(34.6 \%)$ \\
\hline African American & $2(3.8 \%)$ \\
\hline Indian & $5(9.6 \%)$ \\
\hline Unknow & $23(44.2 \%)$ \\
\hline \multicolumn{2}{|l|}{ Presentation } \\
\hline Bone Pain & $23(44.2 \%)$ \\
\hline Fatigue & $18(34.6 \%)$ \\
\hline plasmacytoma & $18(34.6 \%)$ \\
\hline
\end{tabular}


Citation: Wu J, Chu E, Chase CC, Choi T, Gasparetto C, Young K, Kang Y. Anaplastic Multiple Myeloma: Case Series and Literature Review. Asp Biomed Clin Case Rep. 2022 Jan 15;5(1):1-11.

\section{Case Series}

\begin{tabular}{|c|c|}
\hline Fever & $4(7.7 \%)$ \\
\hline Pathologic fracture & $3(5.8 \%)$ \\
\hline Weight loss & $7(13.5 \%)$ \\
\hline Night sweats & $2(3.8 \%)$ \\
\hline Anemia & $3(5 \cdot 7 \%)$ \\
\hline Mental status changed & $3(5.8 \%)$ \\
\hline Dyspnea & $2(3.8 \%)$ \\
\hline Thrombocytopenia & $5(9.6 \%)$ \\
\hline Renal insufficiency & $1(1.9 \%)$ \\
\hline Abdominal pain & $3(5 \cdot 7 \%)$ \\
\hline \multicolumn{2}{|l|}{ M protein } \\
\hline IgG & $13(25 \%)$ \\
\hline $\operatorname{IgA}$ & $17(32.7 \%)$ \\
\hline $\operatorname{IgM}$ & $1(1.9 \%)$ \\
\hline $\operatorname{Ig} \mathrm{D}$ & $1(1.9 \%)$ \\
\hline \multicolumn{2}{|l|}{ Cytogenetics } \\
\hline TP53 & $9(17.3 \%)$ \\
\hline t $(11 ; 14)$ & $7(13.4 \%)$ \\
\hline t $(4 ; 14)$ & $5(9.6 \%)$ \\
\hline$t(14,16)$ & $1(1.9 \%)$ \\
\hline hyperdiploidy & $1(1.9 \%)$ \\
\hline Del 13 & $8(15.4 \%)$ \\
\hline 1q amplification & $12(23 \%)$ \\
\hline \multicolumn{2}{|l|}{ Treatments } \\
\hline HSCT & $9(17 \cdot 3 \%)$ \\
\hline VRD (Dexamethasone, Lenalidomide and Bortezomib) & $2(3.8 \%)$ \\
\hline VD (Bortezomib, Dexamethasone) & $2(3.8 \%)$ \\
\hline VCD (Bortezomib, Cyclophosphamide and Dexamethasone) & $10(19.2)$ \\
\hline VDD (Bortezomib, Doxorubicin, and Dexamethasone) & $6(11.5 \%)$ \\
\hline VTD (Bortezomib, Thalidomide and Dexamethasone) & $6(11.5 \%)$ \\
\hline VAD (Vincristine, Adriamycin and Dexamethasone) & $1(1.9 \%)$ \\
\hline BD (Bortezomib, Dexamethasone) & $1(1.9 \%)$ \\
\hline DVD (Daratumumab, Bortezomib and Dexamethasone) & $1(1.9 \%)$ \\
\hline KD (Carfilzomib, Dexamethasone) & $2(3.8 \%)$ \\
\hline Melphalan, cyclophosphamide, vincristine, prednisone & $14(26.9 \%)$ \\
\hline RCD (Lenalidomide, Cyclophosphamide and Dexamethasone) & $1(1.9 \%)$ \\
\hline VDD (Vincristine, Doxorubicin, and Dexamethasone) & $3(5.8 \%)$ \\
\hline TD (Lenalidomide, Dexamethasone) & $1(1.9 \%)$ \\
\hline \multicolumn{2}{|l|}{ Outcomes } \\
\hline$<1$ month & $2(3.8 \%)$ \\
\hline 1-6 months & $21(40.38 \%)$ \\
\hline 6-12 months & $2(3.8 \%)$ \\
\hline 12-24 months & $12(23.1 \%)$ \\
\hline$>24$ months & $4(7.6 \%)$ \\
\hline Median Survival (months) & 4 \\
\hline
\end{tabular}


Citation: Wu J, Chu E, Chase CC, Choi T, Gasparetto C, Young K, Kang Y. Anaplastic Multiple Myeloma: Case Series and Literature Review. Asp Biomed Clin Case Rep. 2022 Jan 15;5(1):1-11.

male and 26 were female with the mean age being 57.02 years old (Table-1). AMM occurred in all ethnic groups. Unlike plasmablastic lymphoma, most AMM patients did not have pre-existing HIV conditions. The initial presentation of AMM in most patients consisted of fatigue (34.6\%), bone pain (44.2\%), and weight loss $(13.5 \%)$. It is also interesting to note that thrombocytopenia was in the initial presentation in 9.6\% of patients. Eighteen cases (34.6\%) presented with extramedullary plasmacytoma involving right brachial plexus [4], pancreatic involvement [5], brain [8], soft tissue [18], intraperitoneal mass [11], liver [19], and left parotid region [23], etc. IgA was the most common $M$ protein subtype (32.7\%) and $1 \mathrm{q}$ amplification was the most prevalent cytogenic abnormality (23\%). Patients with AMM were typically treated with standard regular MM regimens such as VCD (Bortezomib + Cyclophosphamide+ Dexamethasone), or VAD (Vincristine + Adriamycin+ Dexamethasone), and /or VTD (Bortezomib + Thalidomide + Dexamethasone), and in $17.3 \%$ of patients followed by consolidation with autologous hematopoietic stem cell transplant (HSCT). Unfortunately, $\sim 44 \%$ of patients with AMM did not survive the past 6 months and only $7.6 \%$ of patients survived over 24 months. The median survival was 4 months.

\section{Cases Series:}

To investigate the outcomes of patients with AMM in the current era of treatment, we performed a retrospective case study at our institute. The retrospective chart review was performed in accordance with the ethical standards of Duke University Institutional Review Board (IRB) Committees on human experimentation and was approved by the Duke IRB committee. We queried and searched Duke electronic medical records from December 2012 to July 2021 and identified 14 patients with AMM to be included for the study. The patient inclusion criteria are having a diagnosis of AMM confirmed at Duke; and having medical records available that include laboratory data at the time of diagnosis, treatment regiment, and survival status. Detailed information regarding clinical presentation, laboratory finding, imaging tests, and treatment were extracted and included: age at the time of diagnosis, gender, race, date of diagnosis, laboratory values, PET $\mathrm{CT}$ and other imaging, bone marrow biopsy (plasma cell percentage), disease stage (International Stage Index), cytogenetics (karyotype and FISH), treatment regimens including hematopoietic stem cell transplant, progression-free survival, and overall survival.

We identified 14 patients with AMM at our institute between December 2012 to July 2021. Male patients accounted for $85.7 \%$ of the cases with only 2 female patients in our cohort. The mean age at diagnosis was 59 years old, ranging from 46 to 85 years old. All ethnic groups (Caucasian, African American, Hispanic, and Asian) are affected. 9 patients (64.3\%) presented with de novo AMM, whereas in 5 patients (35.7\%) AMM was transformed from pre-existing myeloma and presented at the time of myeloma relapse. The majority of the AMM patients (12 patients, 85.7\%) demonstrated extensive osseous lytic lesions and/or plasmacytoma. The diffuse fluorodeoxyglucose avidity and several bones and extramedullary lesions in one of the AMM patients were shown in the PET CT scan (Fig-1). IgA subtype accounted for $28.6 \%$ of the

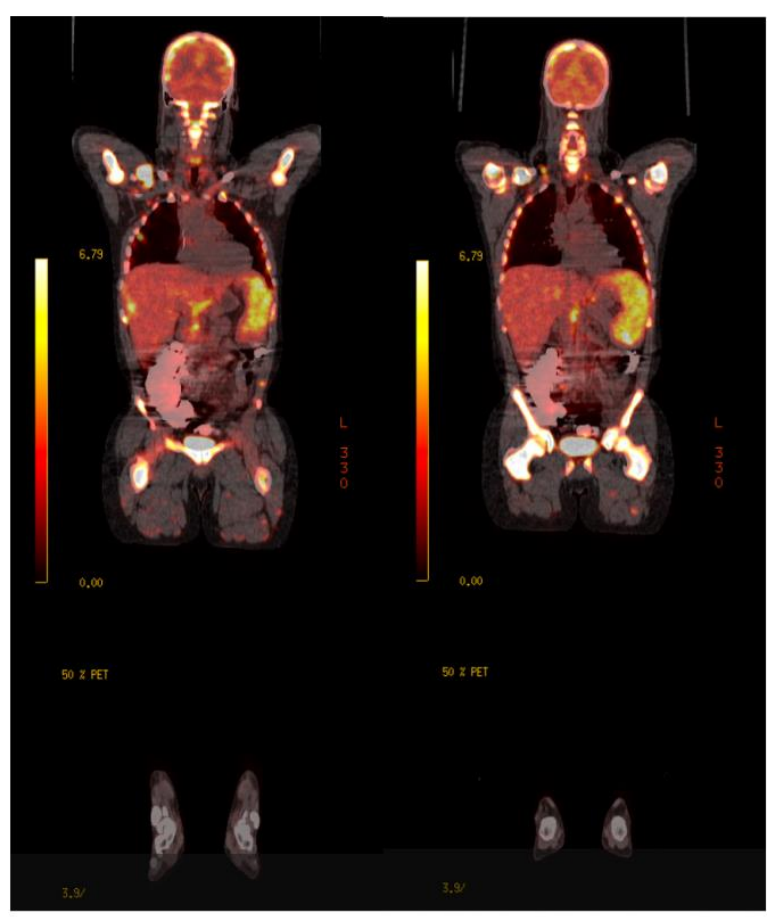

Fig-1: 18F-FDG PET/CT in one patient with multiple myeloma

18F-FDG PET/CT scan demonstrates intense hypermetabolic FDG activity in patient with anaplastic multiple myeloma. 18F-FDG, 18F-flurodeoxyglucose, PET, positron emission tomography; CT, computed tomography. 
Citation: Wu J, Chu E, Chase CC, Choi T, Gasparetto C, Young K, Kang Y. Anaplastic Multiple Myeloma: Case Series and Literature Review. Asp Biomed Clin Case Rep. 2022 Jan 15;5(1):1-11.

patients. Amplification of 19 occurred in $50 \%$ of the patients and is the most common genetic abnormality in AMM (Table-2). The tumor cells were primitiveappearing and anaplastic and could resemble poorly differentiated immunoblast-like cells (Fig-2). The

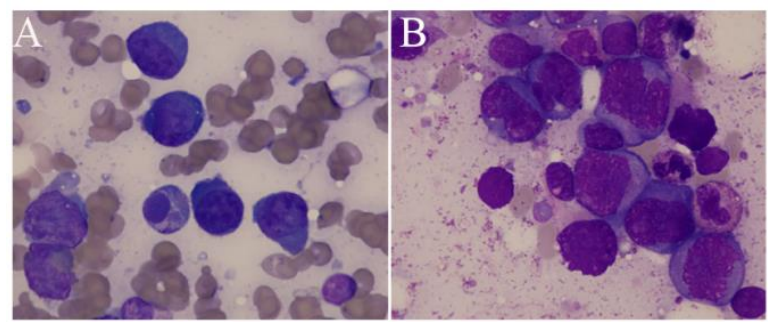

Fig-2: Peripheral blood and bone marrow evaluation showed sheets of neoplastic cells with many anaplastic forms

(A) Peripheral blood smear (50 $\times$ ) showing morphological changes in anaplastic myeloma cells. (B) On bone marrow aspirate, the anaplastic cells resembled dysplastic megakaryocytes with purple-bluish granular cytoplasm and bizarre or separated nuclei.

infiltrating plasma cells were positive for $\mathrm{CD} 138$ with light chain restriction. The nuclear Ki-67 expression could be high, in some cases, the nuclear Ki-67 expression could reach over 90\%, indicating a high proliferation fraction. The expression of CD117, cyclin D1, and CD56 could be highly variable (Fig-3) and the plasma cells could also be positive for CD2o (data not shown).

AMM patients were treated with standard MM regimen including VRD (Bortezomib + Revlimid+
Dexamethasone), or VCD (Bortezomib + Cyclophosphamide + Dexamethasone), and /or VDPACE regimen. 7 patients $(50 \%)$ received high dose melphalan conditioning followed by autologous HSCT. Despite receiving standard MM treatment, the median progression-free survival (PFS) for our 14 AMM patients was 0.84 years, and the median overall survival (OS) was 1.52 years.

We compared the treatment outcomes of our 14 AMM patients with a historical dataset of 393 regular MM patients treated at our institute from 2003 to 2013. The patient characteristics and treatment of our 393 regular MM patients were summarized in Table-3. Although our regular MM patients were treated 10 years earlier, the PFS and OS of the patients with AMM were significantly worse than those in patients with regular MM: PFS was 0.84 years and 2.28 years for $\mathrm{AMM}$ and regular $\mathrm{MM}$, respectively $(\mathrm{p}=0.0364)$. The OS was 1.52years and 4.92 years for AMM and regular $\mathrm{MM}$, respectively $(\mathrm{p}=0.0003)$ (Fig-4).
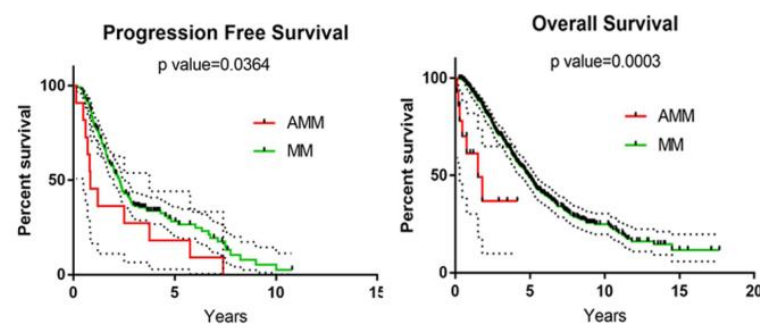

Fig-4: The progression free survival and overall survival analysis between AMM and regular MM
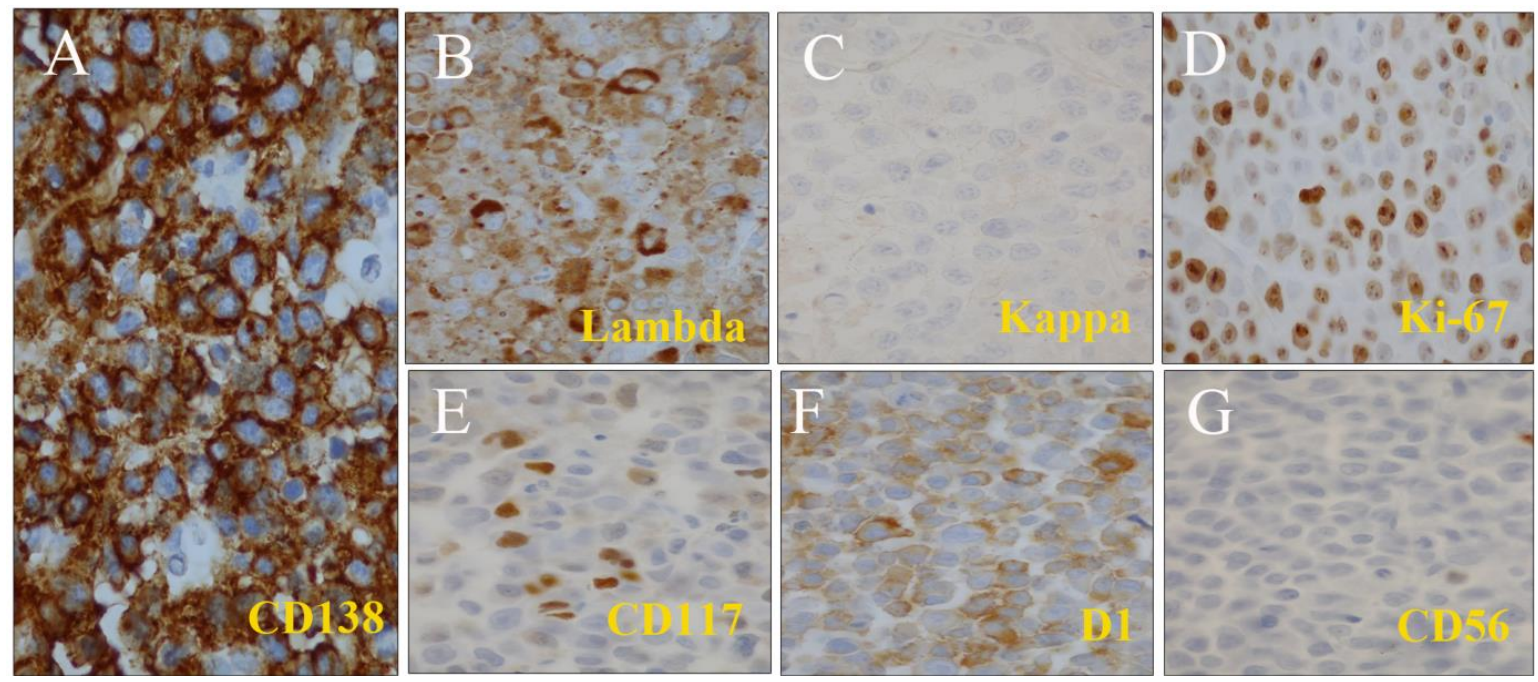

Fig-3: Pathological findings of bone marrow at diagnosis

The neoplastic cells were positive for $C D 138$ (A) and cytoplasmic lambda light chain (B), and negative for cytoplasmic kappa light chain (C). The neoplastic cells were positive for Ki67 (D), CD117 (E) but negative for $C_{5} 6(F)$. 
Citation: Wu J, Chu E, Chase CC, Choi T, Gasparetto C, Young K, Kang Y. Anaplastic Multiple Myeloma: Case Series and Literature Review. Asp Biomed Clin Case Rep. 2022 Jan 15;5(1):1-11.

Case Series

Table-2: AMM: Patient Characteristics, Treatment, and Outcomes: Duke cases

\begin{tabular}{|c|c|}
\hline & $\begin{array}{c}\text { Patients }(n=14) \\
\text { No. (\%) }\end{array}$ \\
\hline \multicolumn{2}{|l|}{ Gender (n, \%) } \\
\hline Male & $12(85.7 \%)$ \\
\hline Female & $2(14.3 \%)$ \\
\hline Mean age (years) & 59 \\
\hline Range & $46-85$ \\
\hline \multicolumn{2}{|c|}{ De novo vs transformation } \\
\hline De novo & $9(64.3 \%)$ \\
\hline Transformation & $5(35 \cdot 7)$ \\
\hline \multicolumn{2}{|l|}{ Race } \\
\hline Caucasian & $6(42.9 \%)$ \\
\hline African American & $6(42.9 \%)$ \\
\hline Hispanic & $1(7.1 \%)$ \\
\hline Asian & $1(7.1 \%)$ \\
\hline \multicolumn{2}{|l|}{ M protein } \\
\hline $\operatorname{IgG}$ & $7(50 \%)$ \\
\hline IgA & $4(28.6 \%)$ \\
\hline Light chain disease & $3(21.4 \%)$ \\
\hline \multicolumn{2}{|l|}{ Cytogenetics } \\
\hline 1q amplification & $7(50 \%)$ \\
\hline TP53 deletion & $3(21.1 \%)$ \\
\hline $\operatorname{Del}(13)$ & $6(42.9 \%)$ \\
\hline $\mathrm{t}(11 ; 14)$ & o \\
\hline$t(4 ; 14)$ & $3(21.4 \%)$ \\
\hline t $(4 ; 16)$ & $1(7.1 \%)$ \\
\hline Hyperdiploidity & $5(35 \cdot 7 \%)$ \\
\hline \multicolumn{2}{|l|}{ ISS stage } \\
\hline I & $4(28.6 \%)$ \\
\hline II & $3(21.4 \%)$ \\
\hline III & $4(28.6 \%)$ \\
\hline Unknown & $3(21.4 \%)$ \\
\hline \multicolumn{2}{|l|}{ Treatment } \\
\hline VCD/VRD & $12(85 \cdot 7 \%)$ \\
\hline VD-PACE & $4(28.6 \%)$ \\
\hline Autologous HSCT & $7(50 \%)$ \\
\hline PFS (Median) & 0.84 years \\
\hline OS (Median) & 1.52 years \\
\hline
\end{tabular}


Citation: Wu J, Chu E, Chase CC, Choi T, Gasparetto C, Young K, Kang Y. Anaplastic Multiple Myeloma: Case Series and Literature Review. Asp Biomed Clin Case Rep. 2022 Jan 15;5(1):1-11.

Case Series

Table-3 Regular MM: Patient Characteristics, Treatment, and Outcomes: Duke cases

\begin{tabular}{|c|c|}
\hline & $\begin{array}{l}\text { Regular MM of Duke records } \\
\qquad(n=393)\end{array}$ \\
\hline \multicolumn{2}{|l|}{ Gender (n, \%) } \\
\hline Male & $217(55.2 \%)$ \\
\hline Female & $176(44.8 \%)$ \\
\hline \multicolumn{2}{|l|}{ Age (years) } \\
\hline Median (range) & $60(31-88)$ \\
\hline \multicolumn{2}{|l|}{ Race } \\
\hline Caucasian & $246(62.9 \%)$ \\
\hline African American & $129(33 \%)$ \\
\hline Asian & $3(0.8 \%)$ \\
\hline Hispanic & $1(0.3 \%)$ \\
\hline Native American & $8(2.0 \%)$ \\
\hline Other & $4(1.0 \%)$ \\
\hline \multicolumn{2}{|c|}{ Cytogenetic stratification } \\
\hline Standard & $246(66.5 \%)$ \\
\hline Intermediate & $20(5.4 \%)$ \\
\hline High risk & $37(10.0 \%)$ \\
\hline Unknown & $67(18.1 \%)$ \\
\hline \multicolumn{2}{|l|}{ M protein type } \\
\hline Ig G & $244(69.3 \%)$ \\
\hline $\operatorname{Ig} \mathrm{A}$ & $84(23.9 \%)$ \\
\hline $\operatorname{Ig} \mathrm{M}$ & $3(0.9 \%)$ \\
\hline Ig D & $2(0.6 \%)$ \\
\hline Other & $21(6.0 \%)$ \\
\hline \multicolumn{2}{|l|}{ ISS stage } \\
\hline I & $74(20.8 \%)$ \\
\hline II & $84(23.7 \%)$ \\
\hline III & $84(23.7 \%)$ \\
\hline Unknown & $113(31.8 \%)$ \\
\hline \multicolumn{2}{|c|}{ Bone lytic lesion } \\
\hline Yes & $199(52.9 \%)$ \\
\hline No & $122(32.4 \%)$ \\
\hline Unknown & $55(14.6 \%)$ \\
\hline \multicolumn{2}{|l|}{ Treatment } \\
\hline HSCT & $213(63.4 \%)$ \\
\hline Bortezomib & $299(98.0 \%)$ \\
\hline Carfilzomib & $56(18.4 \%)$ \\
\hline Ixazomib & $6(2.0 \%)$ \\
\hline Thalidomide & $94(29.7 \%)$ \\
\hline Lenalidomide & $274(86.7 \%)$ \\
\hline Pomalidomide & 62 (19.6\%) \\
\hline Panobinostat & $7(36.8 \%)$ \\
\hline Elotuzumab & $1(5 \cdot 3 \%)$ \\
\hline Daratumumab & $8(42.1 \%)$ \\
\hline
\end{tabular}


Citation: Wu J, Chu E, Chase CC, Choi T, Gasparetto C, Young K, Kang Y. Anaplastic Multiple Myeloma: Case Series and Literature Review. Asp Biomed Clin Case Rep. 2022 Jan 15;5(1):1-11.

\begin{tabular}{|l|c|}
\hline CR & $53(16.2 \%)$ \\
\hline VGPR & $93(28.4 \%)$ \\
\hline PR & $122(37.2 \%)$ \\
\hline SD & $22(6.7 \%)$ \\
\hline PD & $21(6.4 \%)$ \\
\hline Unknown & $17(5.2 \%)$ \\
\hline PFS (Median) & 2.28 years \\
\hline OS (Median) & 4.92 years \\
\hline
\end{tabular}

\section{Discussion and Conclusions}

In the current study, we performed a systematic literature review as well as retrospective cohort study in an effort to define clinical characteristics, prognosis, and outcomes of patients with AMM. We found that AMM affects both males and females and all ethnic groups. AMM occurs in a much younger patient population (median age of 57.02 years old) compared to conventional multiple myeloma (median age of 69 years old) [24]. Anemia was one of the most common presentations of AMM and thrombocytopenia occurred in $9.6 \%$ of AMM patients at presentation, which likely reflects the aggressiveness of the disease and the extensive bone marrow infiltration by anaplastic plasma cells [21]. AMM can develop de novo or transform from pre-existing regular multiple myeloma. In contrast to regular multiple myeloma, IgA was the most common M protein subtype (32.7\%) and 19 amplification was the most prevalent cytogenic abnormality (23\%). The prognosis of AMM is dismal and very few AMM patients survived past 24 months after the diagnosis.

In our case series, osseous involvement was very common in AMM patients. It is also interesting to note that in the literature reviews, 18 of the cases presented with extramedullary plasmacytoma (34.6\%) located in the right brachial plexus [4], pancreatic involvement [5], brain [8], soft tissue [18], intraperitoneal mass [11], liver [19], and left parotid region [23], etc. Extramedullary plasmacytoma (EMP) is typically seen in MM patients at disease relapse or as an aggressive disease presentation. The plasma cells in EMP have an immature and plasma-plastic appearance when compared to the plasmacytoma with bone marrow involvement. There was a research that indicates that clonal mutations of $\mathrm{TP}_{53}, \mathrm{RB} 1, \mathrm{FAK}$, and RAS genes have been presented in $50 \%$ of patients who have EMP presentation with MM [25]. In AMM, mutation of TP53 is high, which could possibly lead to increased EMP presentation. More research must be done in order to determine the significance of EMP in AMM patients and how this should be evaluated when developing a standard course of treatment.

The cellular origin of anaplastic multiple myeloma is considered to be immature plasma cells [26]. Morphologically, the diameter of anaplastic myeloma cells is significantly enlarged by approximately twofold. The atypical pleomorphic, multinucleated morphology of anaplastic myeloma cells can mimic multinucleated carcinoma. The anaplastic cells may simulate dysplastic megakaryocytes with bluish granular, basophilic cytoplasm with bizarre multilobed nuclei; the nuclei are hyperchromatic with abnormal distribution. Anaplastic myeloma cells have moderate to abundant basophilic cytoplasm, prominent nucleoli, and intranuclear basophilic inclusions (Fig-2). Therefore, the differential diagnosis for AMM includes metastatic carcinoma, acute leukemia/myeloid dysplastic syndrome with dysplastic megakaryocytes, and plasmablastic lymphoma (PBL). The distinction between AMM and PBL can be difficult. PBL is also a rare subtype of B-lymphoid malignancy, which has pathological features that can overlap with aggressive, mature B-cell lymphomas and plasma cell neoplasms [27]. There are a number of clinicopathological features that will support a diagnosis of AMM, such as renal dysfunction, significant paraprotein level, osteolytic lesions, hypercalcemia, and diffuse bone marrow involvement [28]. The current differential diagnosis between PBL and AMM is focused on the difference in clinical manifestations, such as M-protein levels, HIV infections, and osteolytic changes [29]. Additionally, with the widespread application of FISH and next-generation sequencing, the chromosomal and 
genetic abnormalities that is unique to AMM such as $1 \mathrm{q}$ amplification and translocation of $\mathrm{t}(11 ; 14)$ have made it easier to distinguish PBL from AMM.

Currently, the genetic and molecular mechanisms driving the pathogenesis and the aggressiveness of AMM remain largely uncharacterized. Due to the rarity of the disease, no studies have ever been reported determining the differences in genetic/molecular pathways and/or immune signatures between AMM and regular MM. As shown in our current study, the common chromosomal and FISH abnormalities in AMM included 1q21 amplification, 17p(p53) deletion, $\mathrm{t}$ (4:14), and/or chromosome 13 anomalies. 1q amplification was observed in 50\% of our case series. Cyclin kinase subunit $1 \mathrm{~B}\left(\mathrm{CKS}_{1} \mathrm{~B}\right)$ gene is located at chromosomal locus $1 \mathrm{q} 21$ and was associated with aggressive disease progression and poor prognosis in MM, even after HSCT [30]. CKS1B expression was low to undetectable in healthy subjects and in patients with monoclonal gammopathy of undetermined significance (MGUS), but significantly increased in patients with relapse/refractory $\mathrm{MM}$ [31]. $\mathrm{CKS}_{1 \mathrm{~B}}$ regulates the ubiquitination and proteasomal degradation of p27Kip1 $[32,33]$ and plays an important role in tumor cell proliferation, survival and drug resistance [31]. AMM was associated with a significantly higher prevalence of $\mathrm{CKS} 1 \mathrm{~B}$ amplification compared with regular $\mathrm{MM}$ (91\% vs. $34 \%$ respectively) [10]. Whether $\mathrm{CKS} 1 \mathrm{~B}$ contributes to the pathogenesis of AMM remains to be determined.

AMM is associated with an overall poor prognosis [6]. Most AMM patients have an inadequate response to conventional chemotherapy and radiotherapy $[1,2,4,5,8,10,11,13,14,17,19,21,23]$. In our case series, $66.7 \%$ patients experienced an unsatisfactory response to standard myeloma treatment regimens, that is VRD (Bortezomib, lenalidomide and dexamethasone) and VCD (Bortezomib, lenalidomide and dexamethasone). In two of our patients, VD-PACE regimen was used along with VRD prior to hematopoietic stem cell transplantation (HSCT) consolidation and was able to achieve remission for over 2 years. The utility of chimeric antigen receptor T-cell immunotherapy and bi-specific antibody in AMM remains to be determined.
In conclusion, our current report included 52 cases of AMM in literature review and 14 cases of AMM at our own institute, representing the largest case series of AMM ever reported. AMM is a highly malignant subtype of myeloma with a bizarre morphology and is resistant to conventional therapy. Based on our own experience, aggressive induction chemotherapy combined with novel agents followed by consolidation with autologous stem cell transplant should be offered for patients with AMM. Additional molecular and genetic pathway studies are needed to better understand the pathophysiology. Importantly, clinical trials designed specifically for AMM are urgently needed to develop more effective treatment strategies and improve the prognosis and outcomes of patients with AMM.

\section{Declarations}

\section{Ethics Approval and Consent to Participate:}

The studies involving human patient samples were performed in accordance with the ethical standards of Duke University Institutional Review Board Committees on human experimentation. All of our studies involving animal models were performed in accordance with Duke University Institutional Animal Care and Use Committee approved- procedures.

\section{Consent for Publication:}

This is a retrospective study and informed consent from patients are waived. All authors have given consent for publication.

\section{Data Availability Statement:}

The data that support the findings of this study are available on request from the corresponding author. The data are not publicly available due to privacy or ethical restrictions.

\section{Competing Interests:}

The authors declare that they have no competing interests.

\section{Funding:}

Yubin Kang received research funding from InCyte Corporation and Consultancy fee from Takeda Oncology USA and Sanofi Genzyme Corp. This work 
was supported by NCI Ro1CA197792 (YK), NCI R21CA234701 (YK), and Duke Cancer Center Start-up fund $(\mathrm{YK})$.

\section{Authors' Contributions:}

JW analyzed and interpreted the patient data regarding the anaplastic multiple myeloma. Patient data extraction by CC, TC, CG, KY and YK. Original draft was written by JW, EC and YK. Critical revision and editing undertaken by all authors.

\section{Acknowledgements:}

Not applicable

\section{References}

[1] Foucar K, Raber M, Foucar E, Barlogie B, Sandler CM, Alexanian R. Anaplastic myeloma with massive extramedullary involvement. Report of two cases. Cancer. 1983 Jan 1;51(1):166-74. [PMID: 6336972]

[2] Fujimi A, Nagamachi Y, Yamauchi N, Kanisawa Y. Morphological Transformation of Myeloma Cells into Multilobated Plasma Cell Nuclei within 7 Days in a Case of Secondary Plasma Cell Leukemia That Finally Transformed as Anaplastic Myeloma. Case Rep Hematol. 2017;2017:5758368. [PMID: 29430310]

[3] Xie W, Tang G, Li S, Yin CC, Xu J. Anaplastic multiple myeloma resembling dysplastic megakaryocytes. Clin Case Rep. 2019 Sep 30;8(3):56869. [PMID: 32185061]

[4] Ichikawa S, Fukuhara N, Hatta S, Himuro M, Nasu K, Ono K, Okitsu Y, Kobayashi M, Onishi Y, Ri M, Ichinohasama R, Harigae $H$. Anaplastic multiple myeloma: possible limitations of conventional chemotherapy for long-term remission. J Clin Exp Hematop. 2018;58(1):39-42. [PMID: 29553093]

[5] Singh N, Agrawal N, Mehta A, Panaych A, Sekhri R. CD38-Negative Myeloma with Anaplastic Morphology at Presentation: A Case Report. Indian J Hematol Blood Transfus. 2018 Apr;34(2):362-64. [PMID: 29622888]

[6] Sethi S, Miller I. Plasma cell myeloma with anaplastic transformation. Blood. 2016 Oct 20;128(16):2106. [PMID: 28157681]

[7] Harankhedkar S, Gupta R, Rahman K. Pleomorphic Multinucleated Plasma Cells Simulating Megakaryocytes in an Anaplastic Variant of Myeloma. Turk J Haematol. 2018 May 25;35(2):150-51. [PMID: 29405120]
[8] Ammannagari N, Celotto K, Neppalli V, Lee K, Holstein SA. Anaplastic Multiple Myeloma: An Aggressive Variant With a Poor Response to Novel Therapies. Clin Lymphoma Myeloma Leuk. 2016 Sep;16(9):e129-31. [PMID: 27375159]

[9] Chang H, Kajal B. Anaplastic variant of plasma cell myeloma with Dutcher bodies. Blood. 2016 Jun 23;127(25):3291. [PMID: 28092870]

[10] Bahmanyar M, Qi X, Chang H. Genomic aberrations in anaplastic multiple myeloma: high frequency of $1 \mathrm{q} 21\left(\mathrm{CKS}_{1} \mathrm{~B}\right)$ amplifications. Leuk Res. 2013 Dec;37(12):1726-28. [PMID: 24169o86]

[11] Huang JX, Meng FJ, Feng XQ, Lyu X, Wang X. Clinical and histopathological analyses of anaplastic myeloma. Chin Med J (Engl). 2020 Jul 5;133(13):161416. [PMID: 32558702]

[12] Subitha K, Renu T, Lillykutty P, Letha V. Anaplastic myeloma presenting as mandibular swelling: Diagnosis by cytology. J Cytol. 2014 Apr;31(2):114-16. [PMID: 25210245]

[13] Jiang DZ, Deng CH, Jia YH, Zhang L, Wang ZS, Liu SQ, Gao QP, Zhang QP. Anaplastic myeloma and T-cell lymphoma in the same patient. Chin Med J (Engl). 2013 Mar;126(5):996. [PMID: 23489822]

[14] Beljan Perak R, Karaman I, Sundov D, Jakelic Pitesa J, Novak A, Pavlovic A. Anaplastic Variant of Plasma Cell Myeloma: A Pitfall of Morphlogical Identification. Acta Cytol. 2016;6o(3):275-76. [PMID: 27428051]

[15] Strand WR, Banks PM, Kyle RA. Anaplastic plasma cell myeloma and immunoblastic lymphoma. Clinical, pathologic, and immunologic comparison. Am J Med. 1984 May;76(5):861-67. [PMID: 6547021]

[16] Raman Ramalingam T, Vaidhyanathan L, Pandurangan P. Anaplastic plasma cell myeloma - A morphological dilemma. Hematol Transfus Cell Ther. 2020 Aug 5:S2531-1379(20)30112-7. [PMID: 32782205]

[17] Saburi M, Ogata M, Soga Y, Kondo Y, Kurimoto R, Itani K, Kohno K, Uchida H, Nakayama T. Poor response to daratumumab and carfilzomib in newly diagnosed anaplastic multiple myeloma. J Clin Exp Hematop. 2020;6o(1):17-20. [PMID: 32224561]

[18] Tang W, Xu Y, Xiang B. Successful outcome of anaplastic multiple myeloma with lenalidomide, cyclophosphamide, and dexamethasone therapy. Ann Hematol. 2021 Dec;100(12):3039-40. [PMID: 32876702] 
[19] Agrawal M, Kanakry J, Arnold CA, Suzman DL, Mathieu L, Kasamon YL, Gladstone DE, Ambinder RF, Ghosh N. Sustained remission and reversal of endorgan dysfunction in a patient with anaplastic myeloma. Ann Hematol. 2014 Jul;93(7):1245-46. [PMID: 24232305]

[20] Maslovsky I, Lugassy G, Blumental R, Ducach A, Yehuda O, Abeliovich D. Multiple chromosomal abnormalities in fulminant anaplastic myeloma. Clin Lab Haematol. 1999 Jun;21(3):207-10. [PMID: 10448603]

[21] Taccone FS, Bouko Y, Robin V. Exceptional association of diffuse anaplastic myeloma with microangiopathic anemia. Eur J Intern Med. 2007 Dec;18(8):6o7. [PMID: 18054716]

[22] Rao S, Kar R, Pati HP. Anaplastic myeloma: a morphologic diagnostic dilemma. Indian J Hematol Blood Transfus. 2008 Dec;24(4):188-89. [PMID: 23100962]

[23] Stewart JM, Krishnamurthy S. Fine-needle aspiration cytology of a case of HIV-associated anaplastic myeloma. Diagn Cytopathol. 2002 Oct;27(4):218-22. [PMID: 12357499]

[24] Dimopoulos MA, Stewart AK, Masszi T, Špička I, Oriol A, Hájek R, Rosiñol L, Siegel D, Mihaylov GG, Goranova-Marinova V, Rajnics P, Suvorov A, Niesvizky R, Jakubowiak A, San-Miguel J, Ludwig H, Palumbo A, Obreja M, Aggarwal S, Moreau P. Carfilzomib, lenalidomide, and dexamethasone in patients with relapsed multiple myeloma categorised by age: secondary analysis from the phase 3 ASPIRE study. Br J Haematol. 2017 May;177(3):404-13. [PMID: 2821156o] [25] Morales-Chacón K, Bourlon MT, Martínez-Baños D, Delgado-de-la-Mora J, Bourlon C. Multiple Myeloma With Extramedullary Disease: A Challenging Clinical Dilemma. Oncology (Williston Park). 2019 Apr 15;33(4):149-51,155. [PMID: 30990568]

[26] Vega F, Chang CC, Medeiros LJ, Udden MM, Cho-Vega JH, Lau CC, Finch CJ, Vilchez RA, McGregor D, Jorgensen JL. Plasmablastic lymphomas and plasmablastic plasma cell myelomas have nearly identical immunophenotypic profiles. Mod Pathol. 2005 Jun;18(6):8o6-15. Erratum in: Mod Pathol. 2005 Jun;18(6):873. Medeiros, Leonard J [corrected to Medeiros, L Jeffrey]. [PMID: 15578069]

[27] Harmon CM, Smith LB. Plasmablastic Lymphoma: A Review of Clinicopathologic Features and Differential Diagnosis. Arch Pathol Lab Med. 2016 Oct;140(10):1074-78. [PMID: 27684979]

[28] Lorsbach RB, Hsi ED, Dogan A, Fend F. Plasma cell myeloma and related neoplasms. Am J Clin Pathol. 2011 Aug;136(2):168-82. [PMID: 21757591]

[29] Jain BB, Majumdar A, Chowdhary KM. Plasmablastic lymphoma versus anaplastic myeloma in a human immunodeficiency virus negative male: a diagnostic quandary. Arch Iran Med. 2013 Oct;16(10):6o8-10. [PMID: 24093145]

[30] Shah GL, Landau H, Londono D, Devlin SM, Kosuri S, Lesokhin AM, Lendvai N, Hassoun H, Chung DJ, Koehne G, Jhanwar SC, Landgren O, Levine R, Giralt SA. Gain of chromosome 1q portends worse prognosis in multiple myeloma despite novel agentbased induction regimens and autologous $\begin{array}{lll}\text { transplantation. Leuk } & \text { Lymphoma. } & 2017\end{array}$ Aug;58(8):1823-31. [PMID: 28078910]

[31] Zhan FH, Barlogie B, John D S Jr. Gene expression profiling defines a high-risk entity of multiple myeloma. Zhong Nan Da Xue Xue Bao Yi Xue Ban. 2007 Apr;32(2):191-203. [PMID: 17478923]

[32] Spruck C, Strohmaier H, Watson M, Smith AP, Ryan A, Krek TW, Reed SI. A CDK-independent function of mammalian Cks1: targeting of SCF(Skp2) to the CDK inhibitor p27Kip1. Mol Cell. 2001 Mar;7(3):639-50. [PMID: 11463388]

[33] Ganoth D, Bornstein G, Ko TK, Larsen B, Tyers M, Pagano M, Hershko A. The cell-cycle regulatory protein Cks1 is required for SCF(Skp2)-mediated ubiquitinylation of p27. Nat Cell Biol. 2001 Mar;3(3):321-24. [PMID: 11231585] 